\title{
Analisis Perubahan Konsentrasi Total Suspended Solids (TSS) Dampak Bencana Lumpur Sidoarjo Menggunakan Citra Landsat Multi Temporal (Studi Kasus: Sungai Porong, Sidoarjo)
}

\author{
Syaiful Budianto dan Teguh Hariyanto \\ Jurusan Teknik Geomatika, Fakultas Teknik Sipil dan Perencanaan, Institut Teknologi Sepuluh Nopember (ITS) \\ Jl. Arief Rahman Hakim, Surabaya 60111 Indonesia \\ e-mail: Syaifulbudi.a@gmail.com, teguh_hr@geodesy.its.ac.id
}

\begin{abstract}
Abstrak-Sungai Porong merupakan area pembuangan Lumpur Lapindo, tidak menutup kemungkinan bahwa dengan adanya aliran lumpur lapindo mengakibatkan material lumpur tidak banyak mengendap di sepanjang sungai, tetapi mengendap di daerah muara Sungai Porong hingga ke sepanjang pantai . Oleh karena itu metode penginderaan jauh dengan citra satelit dapat menjadi solusi untuk melakukan penelitian masalah TSS (Total Suspended Solids) yang menjadi salah satu parameter dampak sedimentasi di daerah perairan tersebut. Citra satelit yang digunakan dalam penelitian ini adalah citra Landasat 8 L1T hasil perekemanan secara multi temporal pada tahun 2014 sampai dengan tahun 2016 sehingga dapat diketahui nilai dan persebaran TSS (Total Sediment Solid).

Penelitian ini menggunakan 3 algoritma untuk menentukan nilai TSS yaitu, algoritma Guzman dan Santaella (2009), algoritma Syarif Budiman (2004), dan algoritma Laili (2015). Waktu penelitian dilakukan pada musim penghujan yang dilakukan pada bulan april. Daerah penelitian yang digunakan dalam penelitian ini adalah Muara Sungai Porong yaitu di sepanjang pesisir pantai Surabaya - Sidoarjo.

Dari hasil pengolahan data dan analisis didapatkan nilai TSS dari tahun 2014 - 2016 bervariasi antara $1.4 \mathrm{mg} / \mathrm{l}-118 \mathrm{mg} / \mathrm{l}$. Uji validasi nilai TSS yang paling baik dalam penelitian ini adalah perhitungan menggunakan algoritma Laili (2015) dengan Koefisien Determinasi $(\mathbf{R})$ sebesar 73,81 \% dan regresi linier (R2) sebesar 0.5449. Daerah yang mengalami dampak sebaran TSS tinggi adalah muara Sungai Porong, Pantai Pasuruan, muara Kali Alo, selatan Sungai Porong, dan daerah pantai utara Kali Alo. Nilai dan sebaran TSS dipengaruhi oleh pasang surut, arus, angin, dan gelombang. Hasil analisis dan pengolahan data ini dapat dijadikan sebagai bahan referensi dalam penelian selanjutnya.
\end{abstract}

Kata kunci-Algoritma Guzman-Santaella, Algoritma Laili, Algoritma Syarif Budiman, Citra Landsat-8 L1T, Muara Sungai Porong, TSS.

\section{PENDAHULUAN}

$\mathrm{B}$ ENCANA lumpur panas Sidoarjo, juga dikenal dengan sebutan Lumpur Lapindo atau Lumpur Sidoarjo (Lusi), adalah peristiwa menyemburnya lumpur panas di lokasi pengeboran Lapindo Brantas Inc. di Dusun Balongnongo, Desa Renokenongo, Kecamatan Porong, Kabupaten Sidoarjo, Jawa Timur, Indonesia, sejak tanggal 29 Mei 2006 [1]. Kali Porong merupakan area pembuangan Lumpur Lapindo, demikian dilakukan untuk mencegah jebolnya tanggul akibat penuhnya tanggul Lumpur Lapindo. Pembuangan material lumpur dalam jumlah yang besar dan terus menerus mengakibatkan terjadinya sedimentasi di Kali Porong, tidak menutup kemungkinan bahwa adanya aliran lumpur lapindo mengakibatkan material lumpur tidak banyak mengendap di sepanjang kali, tetapi mengendap di daerah muara Kali Porong, yang berada di Selat Madura [6]. TSS merupakan material yang halus di dalam air yang mengandung lanau, bahan organik, mikroorganisme, limbah industri dan limbah rumah tangga yang dapat diketahui beratnya setelah disaring dengan kertas filter ukuran $0.042 \mathrm{~mm}$. Nilai konsentrasi TSS yang tinggi dapat menurunkan aktivitas fotosintesa dan penambahan panas di permukaan air sehingga oksigen yang dilepaskan tumbuhan air menjadi berkurang dan mengakibatkan ikan-ikan menjadi mati [7]. Oleh karena itu metode penginderaan jauh dengan citra satelit dapat menjadi solusi untuk melakukan penelitian masalah TSS (Total Suspended Solid) di daerah perairan Sidoarjo, tepatnya di Muara Kali Porong yang merupakan areal pembuangan lumpur Sidoarjo. Hal ini dilakukan untuk mengetahui seberapa besar sedimentasi yang terjadi pada tahun 2013, 2014, dan 2015 akibat aliran lumpur tersebut.

Melanjutkan dari penelitian-penelitian terdahulu, pada penelitian terdahulu, peneliti telah meneliti masalah sedimentasi menggunakan citra satelit Landsat-7 dengan hasil yang cukup bagus. Dengan adanya hasil yang didapat dari penelitian tersebut dirasa perlu melanjutkan penelitian dengan melakukan analisis menggunakan citra satelit Landsat-8, sehingga digunakan sebagai optimalisasi hasil penelitian sebaran TSS (Total Suspended Solid) untuk kualitas perairan di muara Kali Porong (Perairan Sidoarjo) dan bisa digunakan sebagai acuan untuk penelitian selanjutnya.

\section{METODOLOGI PENELITIAN}

\section{A. Lokasi penelitian}

Lokasi penelitian dari penelitian ini adalah kawasan perairan yang dilalui oleh pembuangan lumpur sidoarjo meliputi sungai Delta Porong hingga Laut Jawa, di Kabupaten Sidoarjo, Jawa Timur. Kawasan area perairan Lumpur Sidoarjo ini secara geografis terletak di antara $7^{\circ} 21^{\prime} 3.22^{\prime \prime}-7^{\circ} 44^{\prime} 57.48^{\prime \prime}$ LS dan $112^{\circ} 47^{\prime} 53.59^{\prime \prime} 113^{\circ} 22^{\prime} 36.48^{\prime \prime B T . ~}$ 


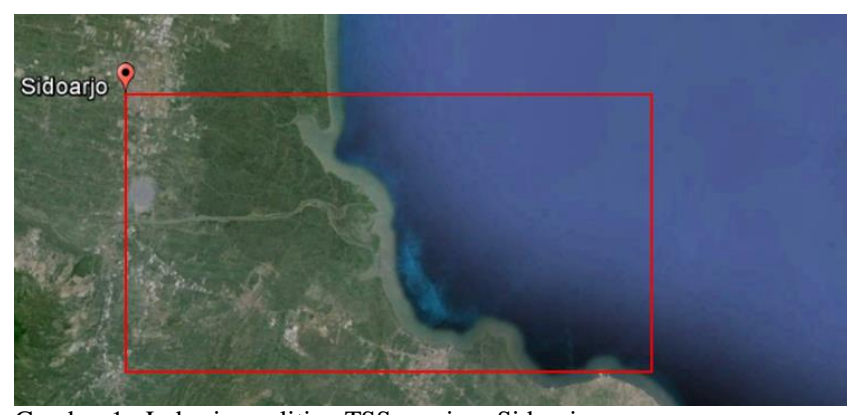

Gambar 1. Lokasi penelitian TSS perairan Sidoarjo

(Sumber: Google Earth 2015) [8]

\section{B. Peralatan dan Data}

Adapun data yang digunakan dalam penelitian penelitian ini, antara lain:

1. Citra satelit Landsat-8 L1T multi temporal pada kawasan perairan terdampak lumpur Sidoajo scene path 118 row 65 tahun 2014,2015 dan 2016;

2. Data nilai TSS di 15 titik pengamatan di lapangan. Data ini akan digunakan sebagai data untuk melakukan validasi dan analisis nilai TSS citra.

Peralatan yang digunakan dalam penelitian ini meliputi:

1. Perangkat Keras (Hardware):

- Notebook,

- GPS navigasi/handheld,

- Perahu motor,

- Jam digital,

- Botol sampel

- Alat Tulis

- Kamera Digital

2. Perangkat Lunak (Software):

- Sistem Operasi Windows 10,

- Microsoft Office 2013,

- Google Earth

- Oruxmaps Free

- ArcGIS 10.3

- Beam VISAT 5.0

\section{Metode Penelitian}

Tahapan yang akan dilaksanakan dalam penelitian penelitian ini adalah:

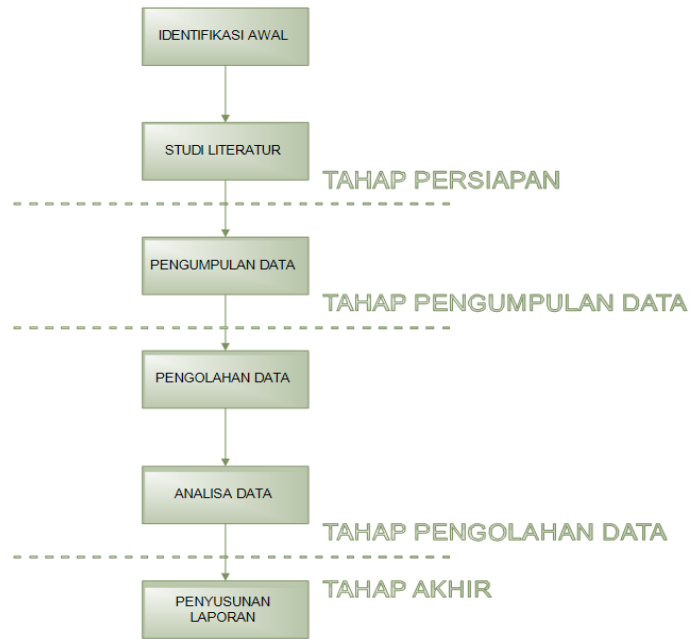

Gambar 2. Diagram Alir Metode Penelitian
Adapun tahap penelitian digambarkan secara umum dengan penjelasan sebagai berikut:

1. Tahap Persiapan

Pada tahap ini, kegiatan-kegiatan yang dilakukan adalah:

i. Identifikasi Awal

Identifikasi awal, bertujuan untuk mengidentifikasi permasalahan dalam suatu penelitian. Adapaun permasalahan dalam penelitian ini adalah bagaimana sebaran konsentrasi beserta perubahan konsentrasi TSS (Total Suspended Solid) pada tahun 2014,2015, dan 2016 di wilayah perairan sidoarjo, selain itu dampak yang ditimbulkan dari perubahan TSS (Total Suspended Solids) tersebut di wilayah perairan sidoarjo akibat pembuangan lumpur.

ii. Studi Literatur

Bertujuan untuk mendapatkan referensi yang berhubungan dengan perhitungan sedimentasi (Total Suspended Solids) menggunakan citra Landsat-8 L1T. Kemudian cara mengklasifikasi citra landsat untuk memisahkan daratan dan perairan dengan algoritka tertentu, dan metode pengumpulan data di lapangan. Semua literatur dicari berdasarkan literatur yang mendukung, baik dari buku, jurnal, paper, makalah ilmiah, internet, dan lain sebagainya.

2. Tahap Pengumpulan Data

Pengumpulan data dilakukan untuk mencari data-data yang menjadi pokok bahasan dalam penelitian penelitian ini. Adapun data yang digunakan dalam penelitian ini, antara lain Citra satelit Landsat-8 L1T multi temporal pada kawasan perairan terdampak lumpur Sidoajo scene path 118 row 65 tahun 2014,2015 dan 2016; dan data nilai TSS di 15 titik pengamatan di lapangan.

3. Tahap Pengolahan Data

Pada tahapan ini dilakukan pengolahan dari data yang telah diperoleh dan data penunjang lainnya.

4. Tahap Analisis

Data yang telah diolah kemudian dianalisis hingga menjadi peta sebaran TSS di perairan Sidoarjo

5. Tahap Akhir

Penyusunan laporan merupakan tahap akhir dari proses penelitian ini sebagai laporan Penelitian ini disertai dokumentasi dari pelaksanaan Penelitian.

\section{Tahapan Pengolahan Data}

\section{Penerapan 3 Algoritma Nilai TSS}

Adapun 3 Algoritma yang digunakan untuk menentukan nilai TSS (Total Suspended Solid), kemudian untuk hasil algoritma yang paling baik akan digunakan untuk menentukan nilai TSS di kawasan Sungai Poroing, ketiga algoritma itu adalah :

Penerapan Algoritma Guzman \& Santaella (2009)

Pada perhitungan nilai TSS yang pertama akan digunakan Algoritma dari penelitian Guzman-Santaella tahun 2009 [3]. Algoritma ini menggunakan nilai reflektan Landsat 8 Band 4 (636-673 nm) dikarenakan panjang gelombang tersebut memberikan nilai reflektan yang baik untuk TSS. Rumus algoritma yang digunakan adalah sebagai berikut :

TSS $(\mathrm{mg} / \mathrm{l})=602.63 *\left(0.0007 \mathrm{e}^{47.755^{*} \text { Landsat BAND 4 }}\right)+3.1481$ 


\section{Penerapan Algoritma Syarif Budiman (2004)}

Pada perhitungan nilai TSS yang kedua akan digunakan algoritma dari penelitian Syarif Budiman (2004) [2]. Rumus algoritma yang digunakan adalah sebagai berikut :

$\operatorname{TSS}(\mathrm{mg} / \mathrm{l})=8.1429 *(\exp (23.704 * 0.94 *$ Band4 $))$

\section{Penerapan Algoritma Laili (2015)}

Pada perhitungan nilai TSS yang ketiga akan digunakan algoritma dari penelitian Nurahida Laili (2015) [5]. Rumus algoritma yang digunakan adalah sebagai berikut :

TSS $(\mathrm{mg} / \mathrm{l})=31.42 *((\log ($ RRS2 $) /(\log ($ RRS4 $))-12.719$

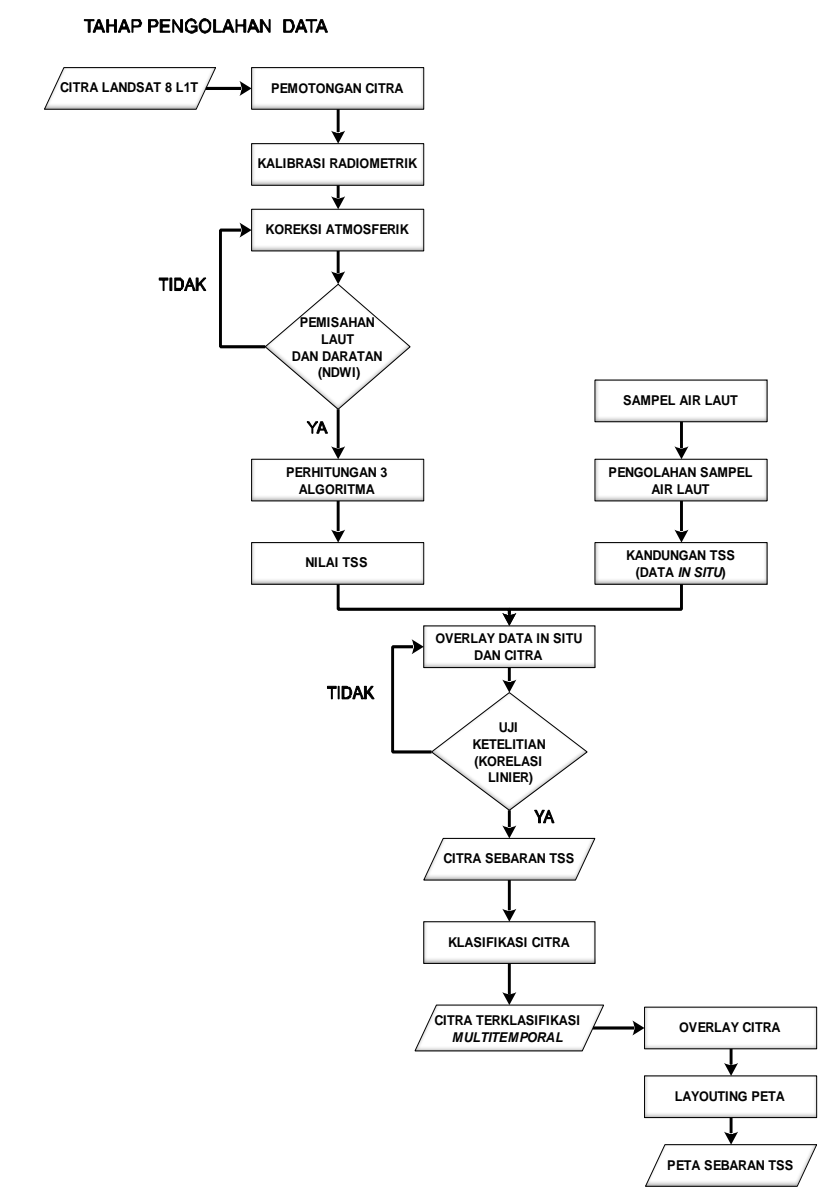

Gambar 3. Diagram Alir Pengolahan Data

\section{HASIL DAN ANALISIS}

A. Perbandingan Nilai TSS Citra 10 Januari 2016 menggunakan 3 algoritma dengan TSS In Situ

1. Perbandingan TSS Citra 10 januari 2016 menggunakan Algoritma TSS Guzman dan Santaella (2009), Algoritma TSS Syarif Budiman (2004), dan Algoritma TSS Laili (2015) dengan TSS In Situ.
Tabel 1.

Nilai Konsentrasi TSS Menggunakan 3 Algoritma Berbeda.

\begin{tabular}{|c|c|c|c|c|c|c|}
\hline \multirow[b]{2}{*}{ No } & \multicolumn{2}{|c|}{ Koordinat Geografis } & \multirow[b]{2}{*}{$\begin{array}{c}\text { TSS In } \\
\text { Situ } \mathrm{mg} / \mathrm{l}\end{array}$} & \multirow{2}{*}{$\begin{array}{l}\text { TSS Citra Tahun } \\
2016 \text { (Algoritma } \\
\text { Guzman)mg/l }\end{array}$} & \multirow{2}{*}{$\begin{array}{l}\text { TSS Citra Tahun } \\
2016 \text { (Algoritma } \\
\text { Laili)mg/l }\end{array}$} & \multirow{2}{*}{$\begin{array}{l}\text { TSS Citra Tahun } \\
2016 \text { (Algoritma } \\
\text { Budiman S)mg/l }\end{array}$} \\
\hline & $\mathrm{x}$ & Y & & & & \\
\hline 1 & 112.8786 & -7.5577 & 48.00 & 16.709 & 17.650 & 13.192 \\
\hline 2 & 112.8786 & -7.5507 & 28.00 & 16.611 & 18.275 & 13.172 \\
\hline 3 & 112.8798 & -7.5425 & 42.72 & 15.156 & 17.044 & 12.912 \\
\hline 4 & 112.8801 & -7.5337 & 72.00 & 20.480 & 18.582 & 13.802 \\
\hline 5 & 112.8693 & -7.5153 & 74.00 & 17.973 & 22.863 & 13.406 \\
\hline 6 & 112.8769 & -7.5194 & 80.00 & 24.790 & 20.749 & 14.419 \\
\hline 7 & 112.8802 & -7.5231 & 70.00 & 27.150 & 21.475 & 14.728 \\
\hline 8 & 112.8825 & -7.5308 & 72.00 & 23.710 & 20.090 & 14.273 \\
\hline 9 & 112.8888 & -7.5387 & 18.00 & 19.624 & 18.463 & 13.671 \\
\hline 10 & 112.8847 & -7.5476 & 84.00 & 27.470 & 20.631 & 14.774 \\
\hline 11 & 112.8855 & -7.5553 & 88.00 & 30.547 & 22.281 & 15.140 \\
\hline 12 & 112.8874 & -7.5621 & 118.00 & 38.610 & 22.383 & 16.049 \\
\hline 13 & 112.8945 & -7.569 & 74.00 & 36.572 & 21.521 & 15.830 \\
\hline 14 & 112.9032 & -7.589 & 42.00 & 27.726 & 20.149 & 14.804 \\
\hline 15 & 112.8947 & -7.5804 & 68.00 & 22.277 & 19.922 & 14.070 \\
\hline
\end{tabular}

B. Validasi Hasil Pengolahan Citra dengan Data Lapangan.

Uji validasi dilakukan menggunakan data Citra Landsat 8 L1T pada tanggal 10 Januari 2016, sedangkan untuk pengambilan data In Situ diambil pada tanggal 20 April 2016. Akan tetapi data In Situ ini dianggap sama dengan waktu pengambilan citra untuk kemudian menjadi bahan identifikasi maupun analisis pada kegiatan penelitian ini. Pada uji validasi dilakukan perhitungan korelasi dengan membandingkan data olahan citra dengan data hasil ground truth TSS yang ada di lapangan. Hal ini digunakan untuk melihat sejauh mana kedekatan atau kebaikan data citra yang digunakan.

Pada uji validasi ini dihasilkan nilai koefisien determinasi sebagai berikut:

- Uji korelasi data lapangan TSS (Total Suspended Solid) dengan data hasil olahan TSS (Total Suspended Solid) Citra Landsat 8 L1T menggunakan Algoritma Guzman dan Santaella (2009) mempunyai nilai koefisien korelasi sebesar $69.35 \%$. Hal ini menjelaskan bahwa ada hubungan antara nilai TSS data citra dengan nilai TSS data In Situ yang baik.

- Uji korelasi data lapangan TSS (Total Suspended Solid) dengan data hasil olahan TSS (Total Suspended Solid) Citra Landsat 8 L1T menggunakan Algoritma Syarif Budiman (2004) mempunyai nilai koefisien korelasi sebesar $69.32 \%$. Hal ini menjelaskan bahwa ada hubungan antara nilai TSS data citra dengan nilai TSS data In Situ yang baik.

- Uji korelasi data lapangan TSS (Total Suspended Solid) dengan data hasil olahan TSS (Total Suspended Solid) Citra Landsat 8 L1T menggunakan Algoritma Nurahida Laili (2015) mempunyai nilai koefisien korelasi sebesar 73,81\%. Hal ini menjelaskan bahwa ada hubungan antara nilai TSS data citra dengan data In Situ yang paling baik apabila dibandingkan dengan 2 algoritma sebelumnya dengan nilai $\mathrm{R}=>0,5-0,75$ atau bisa disebut Korelasi kuat (Sarwono, 2006).

Berikut adalah grafik uji validasi antara data lapangan dengan data citra: 


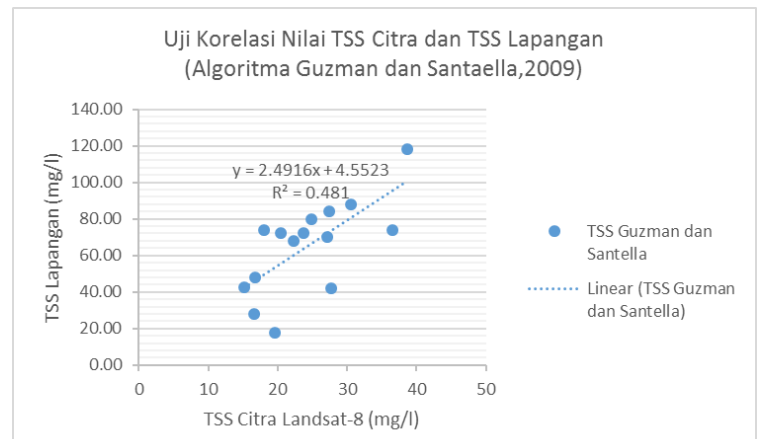

Gambar 4 . Uji Validasi Nilai TSS Algoritma Guzman dan Santaella (2009)

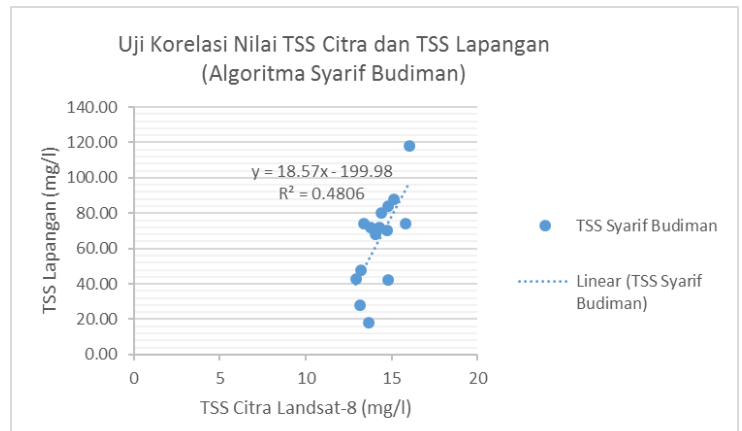

Gambar 5. Uji Validasi Nilai TSS Algoritma Syarif Budiman (2004)

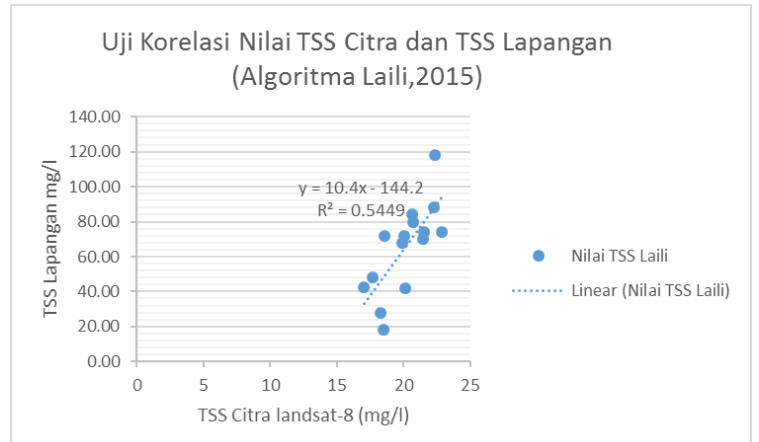

Gambar 6. Uji Validasi Nilai TSS Algoritma Nurahida Laili (2015)

\section{Nilai dan Luas Sebaran TSS Hasil Pengolahan Citra Landsat-8 Tahun 2014-2016}

Selanjutnya dilakukan perhitungan Nilai dan luas sebaran TSS Landsat 8 tahun 2014 hingga tahun 2016, dengan menggunakan algoritma yang paling baik diantara ketiga algoritma yang telah diuji ketelitiannya. Algoritma yang dipakai yaitu algoritma Laili (2015). Adapun data citra dan hasil luas sebaran TSS seperti berikut:

Tabel 4

Tanggal Akuisis Data Citra Landsat 8

\begin{tabular}{llc}
\hline \hline No & Tanggal Akuisisi & Nama File \\
\hline 1 & 25 Maret 2014 & LC81180652014084LGN00_B1.data \\
2 & 29 April 2015 & LC81180652015119LGN00_B1.data \\
3 & 10 Januari 2016 & LC81180652016010LGN00_B1.data \\
\hline \hline
\end{tabular}

Dari tabel 3 dapat dilihat nilai TSS pada tiap titik dan pada tiap tahun. Nilai TSS tiap titik pengamatan tiap tahun tidak selalu naik secara linier, namun kadang juga mengalami penurunan di beberapa titik pengamatan. Untuk lebih jelasnya akan disajikan dalam gambar 3:
Tabel 5.

Nilai TSS tahun 2014-2016

\begin{tabular}{|r|c|c|r|r|r|r|}
\hline \multirow{2}{*}{ No Titik } & \multicolumn{2}{|c|}{ Koordinat Geografis } & \multicolumn{2}{|c|}{ Nilai TSS Per-Tahun di Tiap Titik } & \multicolumn{1}{c|}{ TSS } \\
\cline { 2 - 6 } & $\mathrm{X}$ & $\mathrm{Y}$ & 2014 & 2015 & 2016 & Lapangan \\
\hline 1 & 112.8786 & -7.5577 & 19.506 & 18.832 & 17.650 & 48.00 \\
\hline 2 & 112.8786 & -7.5507 & 17.794 & 19.443 & 18.275 & 28.00 \\
\hline 3 & 112.8798 & -7.5425 & 17.725 & 18.638 & 17.044 & 42.72 \\
\hline 4 & 112.8801 & -7.5337 & 19.467 & 21.977 & 18.582 & 72.00 \\
\hline 5 & 112.8693 & -7.5153 & 20.560 & 22.718 & 22.863 & 74.00 \\
\hline 6 & 112.8769 & -7.5194 & 20.200 & 23.234 & 20.749 & 80.00 \\
\hline 7 & 112.8802 & -7.5231 & 22.901 & 23.530 & 21.475 & 70.00 \\
\hline 8 & 112.8825 & -7.5308 & 20.058 & 22.654 & 20.090 & 72.00 \\
\hline 9 & 112.8888 & -7.5387 & 19.544 & 22.867 & 18.463 & 18.00 \\
\hline 10 & 112.8847 & -7.5476 & 21.123 & 23.096 & 20.631 & 84.00 \\
\hline 11 & 112.8855 & -7.5553 & 20.363 & 23.204 & 22.281 & 88.00 \\
\hline 12 & 112.8874 & -7.5621 & 22.497 & 23.446 & 22.383 & 118.00 \\
\hline 13 & 112.8945 & -7.569 & 22.163 & 23.762 & 21.521 & 74.00 \\
\hline 14 & 112.9032 & -7.589 & 20.891 & 22.303 & 20.149 & 42.00 \\
\hline 15 & 112.8947 & -7.5804 & 18.977 & 20.892 & 19.922 & 68.00 \\
\hline
\end{tabular}

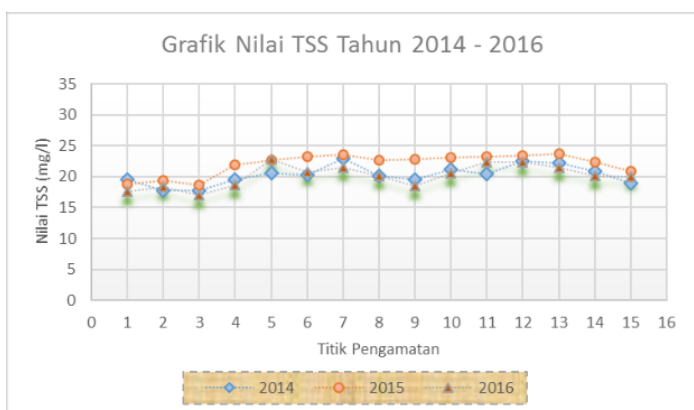

Gambar 7. Grafik Nilai TSS Tahun 2014-2016

Berikut ini akan dijelaskan luas sebaran TSS per tahun hasil pengolahan citra Landsat-8 Tahun 2014-2016:

Tabel 6.

Nilai TSS tahun 2014-2016

Luas Sebaran TSS Per-Tahun di Tiap Titik

\begin{tabular}{crcr} 
Nilai & \multicolumn{3}{c}{ Pengamatan (Ha) } \\
TSS mg/l & 2014 & 2015 & 2016 \\
\hline $0-10$ & 1858.14 & 6983.46 & 4026.96 \\
$10-30$ & 4595.04 & 4723.02 & 10733.04 \\
$30-50$ & 243.36 & 7730.64 & 12390.57 \\
$>50$ & 0.0081 & 5523.48 & 2168.1 \\
\hline \hline
\end{tabular}

Jika disajikan dalam bentuk grafik akan menjadi sebagai berikut :

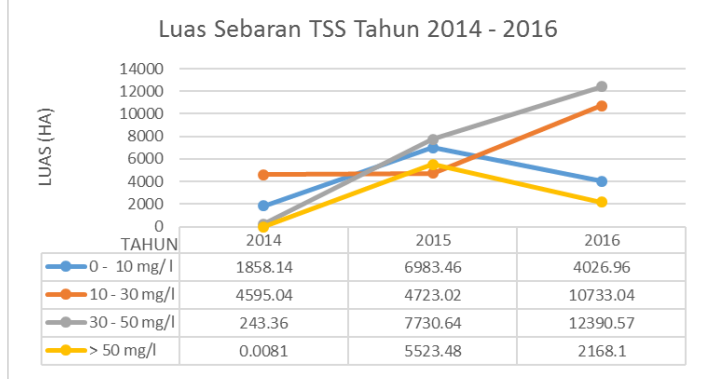

Gambar 8. Luas Sebaran TSS Tahun $2014-2016$

Dari grafik diatas dapat diejlaskan bahwa luas sebaran pada tahun 2014 hingga tahun 2016 tidak selalu naik secara linier, 
namun kadang juga mengalami penurunan sebaran TSS pada konsentrasi tertentu. Pada tahun 2014 luas sebaran terbesar terjadi pada konsentrasi nilai TSS 10 - $30 \mathrm{mg} / \mathrm{l}$ sebesar 4594.04 hektar. Pada tahun 2015 luas sebaran terbesar terjadi pada konsentrasi nilai TSS $30-50 \mathrm{mg} / \mathrm{l}$ sebesar 7730.64 hektar. Sedangkan pada tahun 2016 luas sebaran tebesar terjadi pada konsntrasi TSS 30 - 50 mg/l dengan luas sebaran 12390.57 hektar

D. Analisis Perbandingan Nilai TSS Citra Landsat-8 pada 10 Januari 2016 dengan Data Lapangan.

Nilai $\mathrm{R}^{2}$ yang didapat dari rumus regresi linear menjelaskan bahwa koefisien determinasi dari data citra untuk dapat menggambarkan data di lapangan yang paling baik adalah sebesar 73,81\%. Dari hubungan ini dijelaskan bahwa sebagian besar TSS di lapangan dapat dijelaskan oleh citra, sedangkan sisanya sebesar $26,19 \%$ adalah faktor-faktor lain yang tidak diamati oleh citra. Dengan demikian nilai korelasi yang dihasilkan pada penelitian ini memenuhi syarat yang ditentukan yaitu $\mathrm{R} \geq 70 \%$. Untuk perhitungan TSS menggunakan algoritma lainnya memiliki perbedaan yang cukup menonjol antara citra dan data lapangan hal ini dapat disebabkan karena :

1. Perbedaan waktu perekaman citra dan waktu pengambilan data.

Waktu perekaman citra adalah Tanggal 10 Januari 2016 sedangkan waktu pengambilan data lapangan adalah Tanggal 16 April 2016. Akan tetapi data In Situ dalam penelitian ini dianggap sama untuk kemudian dilakukan analisis dan identifikasi. Dapat dilihat selang waktu yang cukup menonjol terjadi. Hal ini dapat mengakibatkan perubahan / dinamika kondisi perairan yang mengakibatkan perubahan nilai dan sebaran TSS

2. Pengaruh radiometrik

Perbedaan nilai TSS citra dan In Situ dapat disebabkan karena pengaruh radiometrik / gangguan perambambatan gelombang di udara.

\section{E. Analisis Sebaran TSS Tahun 2014-2016}

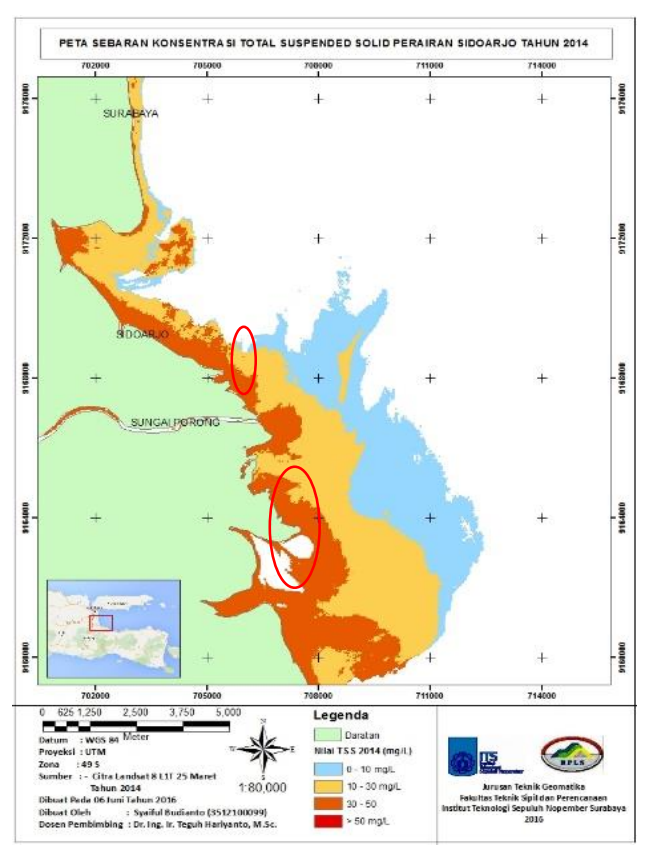

Gambar 9. Sebaran TSS Tahun 2014

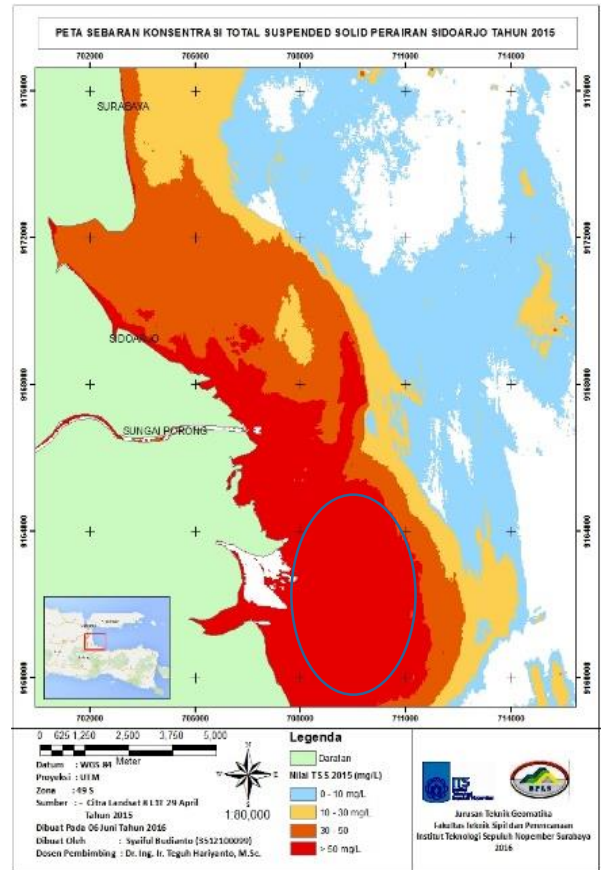

Gambar 10. Peta Sebaran TSS Tahun 2015

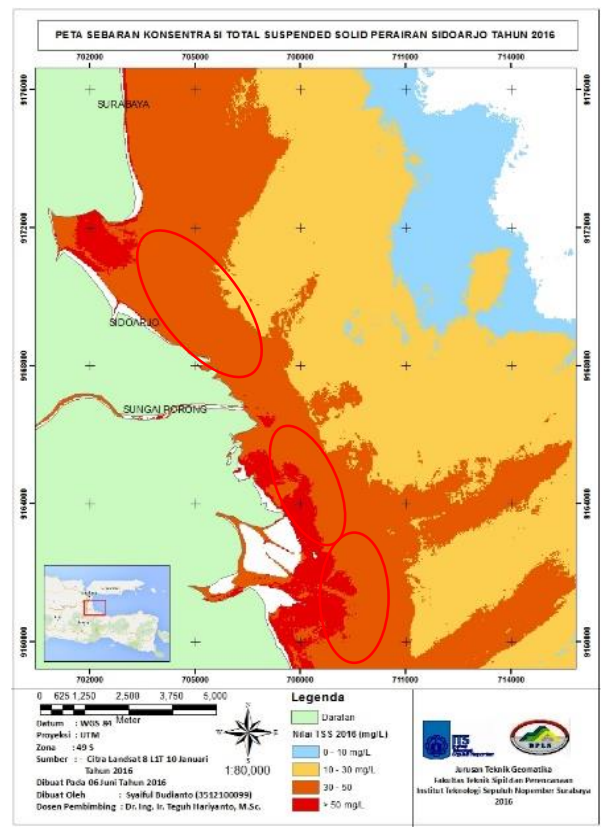

Gambar 11. Peta Sebaran TSS Tahun 2016

Dari peta sebaran TSS tahun 2014-2016 hasil pengolahan citra Landsat 8 di atas dapat dianalisis bahwa nilai dan sebaran TSS di Perairan Sidoarjo yang dikarenakan buangan material lumpur dari kali porong terbilang cukup besar yaitu mencapai $118 \mathrm{mg} / \mathrm{L}$. Daerah yang terkena dampak paling besar adalah di muara Kali Porong karena merupakan tempat bertemunya aliran sungai dan laut (gelombang dan arus) sehingga ada banyak material TSS yang terkonsentrasi di daerah tersebut.

\section{KESIMPULAN/RINGKASAN}

Berdasarkan hasil analisis penelitian ini yang telah di kemukakan, maka dapat diambil kesimpulan sebagai berikut : 
1. Dari peta sebaran TSS tahun 2014-2016 hasil pengolahan citra Landsat 8 di atas dapat dianalisis bahwa nilai TSS di Perairan Sidoarjo yang dikarenakan buangan material lumpur dari kali porong terbilang cukup besar yaitu mencapai $118 \mathrm{mg} / \mathrm{L}$ yang didapatkan dari uji lab TSS menggunakan metode gravimetri. Persebaran konsentrasi TSS terjadi pada muara Kali Porong karena merupakan tempat bertemunya aliran sungai dan laut (gelombang dan arus) sehingga ada banyak material TSS yang terkonsentrasi di daerah tersebut.

2. Dari peta sebaran TSS tahun 2014-2016 hasil pengolahan citra Landsat 8 di atas dapat dianalisis bahwa nilai TSS di Perairan Sidoarjo yang dikarenakan buangan material lumpur dari kali porong terbilang cukup besar yaitu mencapai $118 \mathrm{mg} / \mathrm{L}$ yang didapatkan dari uji lab TSS menggunakan metode gravimetri. Persebaran konsentrasi TSS terjadi pada muara Kali Porong karena merupakan tempat bertemunya aliran sungai dan laut (gelombang dan arus) sehingga ada banyak material TSS yang terkonsentrasi di daerah tersebut.

3. Uji korelasi data lapangan TSS (Total Suspended Solid) dengan data hasil olahan TSS Citra Landsat 8 L1T menggunakan Algoritma Guzman dan Santaella (2009) mempunyai nilai koefisien determinasi sebesar $69.35 \%$, Algoritma Syarif Budiman (2004) mempunyai nilai koefisien determinasi sebesar $69.32 \%$, dan Algoritma Nurahida Laili (2015) mempunyai nilai koefisien determinasi sebesar 73,81\%. Dari data uji korelasi antara data lapangan dengan data citra didapatkan 2 algoritma yang mempunyai hubungan kurang baik / belum memenuhi syarat. Hal ini disebabkan oleh beberapa hal seperti waktu pengambilan data In Situ dengan data citra yang berbeda, penggunaan algoritma yang kurang sesuai dengan daerah penelitian, dan lain sebagainya.

4. Penggunaan citra satelit Landsat 8 pada penelitian konsentrasi nilai TSS pada tahun 2014 hingga 2016 ini menghasilkan nilai $\mathrm{R}^{2}$ paling baik dihasilkan dengan menggunakan algoritma laili (2015), menghasilkan koefisien determinasi sebesar $73,81 \%$. Nilai koefiseien determinasi yang mendekati satu atau $100 \%$ menunjukkan hubungan yang positif, sebaliknya jika $\mathrm{R}^{2}$ mendekati nol, maka memiliki hubungan jelek. Dengan demikian citra Landsat 8 dapat digunakan untuk menggambarkan kondisi Perairan Sidoarjo seperti pada kondisi yang ada di lapangan.

Berdasarkan hasil kesimpulan penelitian ini yang telah di kemukakan, adapun saran yang diberikan penulis;

1. Pengaruh pasang surut, arus, dan angin. Selama selang perbedaan waktu perekaman citra dan pengambilan data lapangan harus diperhatikan peristiwa-peristiwa perubahan pasang surut, arus, dan angin agar tidak mempengaruhi hasil perhitungan konsentrasi nilai TSS.
2. Pengambilan data In Situ sebaiknya dilakukan pada tanggal atau waktu yang sama dengan akuisisi data citra yang akan digunakan.

3. Perlu perhatian dan penanganan khusus dalam masalah TSS ini karena jika dibiarkan terus menerus akan menghasilkan dampak sedimentasi yang parah pada Perairan Sidoarjo.

\section{DAFTAR PUSTAKA}

[1] Akbari, A. M., \& Hariyanto, T. (2012). PERHITUNGAN VOLUME SEMBURAN DAN SEBARAN LUMPUR SIDOARJO DENGAN CITRA. Surabaya: Teknik Geomatika ITS.

[2] Budiman, S. (2004). Mapping TSM Concentrations from Multisensor Satellite Images in Turbid Tropical Coastal Waters of Mahakam Delta. In M. Thesis. Netherland.

[3] Guzman, V. R dan Santaella, F. G. 2009. Using MODIS 250 m Imagery to Estimate Total Suspended Sediment in a Tropical Open Bay. International Journal of System Applications, Engineering \& Development. Issue 1, Volume 3.

[4] Krisna, T. C. (2011). Analisis Sebaran TSS (Total Suspended Solid) Dengan Menggunakan Citra Satelit Aqua Modis Tahun 2005-1011. Surabaya: Teknik Geomatika ITS.

[5] Nurahida Laili, L. J. (2015). Development Of Water Quality Parameter Retrieval Algorithms For Estimating Total Suspended Solids And Chlorophyll-a Concentration Using Landsat-8 Imagery at Poteran Island Water. 55-62.

[6] Walhi, J. (2006). Walhi jatim Tolak Pembuangan Lumpur Lapindo ke Badan Sungai dan Laut. Sidoarjo.

[7] Wirasatriya, A. (2011). Pola Distribusi Klorofil-a dan Total Suspended Solid (TSS) di teluk Toli Toli, Sulawesi. UNDIP.

[8] 2015. Google Earth, <URL : https://earth.google.com/ Dikunjungi pada tanggal 15 maret 2016, jam 21:33. 